\title{
Utilizing Short Tandem Repeats (STRs) as a Resolving Matrix in Parental Dispute DNA Analysis
}

\author{
George Gborienemi Simeon, Alade Tolulope Olukemi \\ Department of Medical Laboratory Science, Niger Delta University, Amassoma, Nigeria \\ Email: ozunugborie@gmail.com
}

How to cite this paper: Simeon, G.G. and Olukemi, A.T. (2018) Utilizing Short Tandem Repeats (STRs) as a Resolving Matrix in Parental Dispute DNA Analysis. American Journal of Molecular Biology, 8, 156-165. https://doi.org/10.4236/ajmb.2018.83013

Received: February 7, 2018

Accepted: June 8, 2018

Published: June 11, 2018

Copyright $\odot 2018$ by authors and Scientific Research Publishing Inc. This work is licensed under the Creative Commons Attribution International License (CC BY 4.0).

http://creativecommons.org/licenses/by/4.0/

\section{(c) (i) Open Access}

\begin{abstract}
Interest in DNA analysis using short tandem repeats (STR) as finger printing tools in forensic medicine has gained tremendous application, as expression of these nuclear factors have enhanced forensic examination. Here we used this Biochemical characterization after conventional extraction process, polymerase chain reaction (PCR), gel electrophoresiss and a sequencer to distinguish and resolve parental dispute. The differential migration of labeled DNA fragments which attains excitation energy with a laser elicits fluorescent light of different wavelength depending on the dye used. A data collection software (Genemapper) collects raw data (spectrograph) and converts it to an electropherogram that is interpreted. By comparing the DNA profiles, inclusion and exclusion criteria were elucidated to resolve disputes. The inherent discriminating power of STRs used in analysis enhances resolution of cell mixtures, genetic aberration, substantiation of tissue origin and provides genetic distinction which is a robust and reliable approach in resolving parental disputes.
\end{abstract}

\section{Keywords}

Short Tandem Repeats, Matrix, Parental, DNA Analysis

\section{Introduction}

The modifications in inherited regions of the DNA from one individual to another which are described as polymorphic regions are very important in forensic cases and paternity disputes. Short tandem repeats which are sub groups of variable number tandem repeats (VNTR) loci are highly abundant in human genome. Usually while measuring in lengths of $2-7$ pairs which are repeated in head-tail manner, short tandem repeat polymorphism are attributed to the dif- 
ferent number of copies of the repeat elements that can occur in a population of individuals [1] [2]. Before using a four locus multiplex short tandem repeat (STR) model into case work, an extensive series of tests were carried out to determine and validate valuable procedures for assessing the evidential proof of a match between crime and suspect scene [3] [4] [5] [6]. Deriving from case work which were analysed from three main ethnic groups earlier encountered in the United Kingdom twelve data bases which were analysed. These ethnic groups include Asians from the Indian sub-region, Caucasian and Afro-Caribbean. Results from these ethnic groups gave credence for the need to investigate the impact it will have on forensic case work [7] [8] [9] [10]. Despite the enormity and quantum of STR contained in the human genome, a very few core set of loci have been selected for use in forensic DNA and human identity testing [11] [12] [13]. Moreover, core loci permit equivalent genetic information to be shared and compared. A detailed process for short tandem repeat typing entails sample collection, DNA extraction, DNA quantitation, PCR amplification of multiplex STR loci allele separation and sizing, short tandem repeat typing and profiling, file interpretation and a repeat of the statistical significance of a match if observed [13]. It has been shown [14] that sometime in casework studies or situations such as sexual assault and evidence, DNA mixture may result from a combination of victim and perpetrating body fluids and create a complex and challenging result to interpret.

After PCR amplification, to determine the overall length of the STR, amplicon is sized. This helps to determine the number of repeats present in each allele found in the DNA profile. This is achieved through a sized-based separation involving gel or capillary electrophoresis. Each STR amplification has been fluorescently labeled during PCR, since either the forward or reverse locus-specific primer contains a fluorescent dye; thus by recording the dye colour and migration time of each DNA fragments relative to an internal standard, the size of each STR allele may be determined following its separation from other STR alleles [15] [16] [17].

There are a number of both biological and instrumental artifacts that often must be sorted out in order to generate a complete accurate STR. As earlier reported [18] [19] known biological artifacts includes vibrant allelic mutation, split peak from incomplete annulation trellis patterns and stutter products [20] [21] [22]. Efforts are ongoing to develop microchips CE platforms to perform high-resolution DNA separations with eventual integration of PCR amplification and CE separation. Moreover, methods such as mass spectrometry (ms) with matrix laser desorption ionization (MALDI) techniques and electrospray ionization (ES) have been used for STR typing without allelic ladder [23].

Most frequently, thirteen short tandem repeat loci are typically used to create a genetic finger print of an individual in forensic laboratories. While some controversies still exist, the DNA data bases in the United Kingdom uses the National Data base. In the United States, the genetic finger prints are kept at vari- 
ous-combined DNA index systems (CODIS) data bases ranging from the smaller local levels to national levels. They have additional benefits of being able to successfully monitor patients following transplant therapy and it is also used to detect or allow for the prediction of problems associated with transplant, such as graft rejection or relapse of the disease.

In this study, we have used 16 STR loci to optimize the use of the powerplex (R) 16 Hs system to elucidate the DNA profiles in a paternity dispute.

\section{Materials and Methods}

Whole blood was collected from alleged Fathers $\mathrm{X}$ and $\mathrm{Y}$ and the Child in dispute, $\mathrm{Z}$ after obtaining their consent. A drop each of their blood sample were impregnated on a nucleic acid card (product of COPAN) and labeled appropriately with name and laboratory number. The drop of blood was allowed to dry and the blood sport was punched with a $1.2 \mathrm{~mm}$ Harris Punch. Sample preparation was done in a Biosafety Cabinet as follows:

$\begin{array}{lll}\text { Reagent } & \text { Positive } & \text { Test Sample(s) } \\ \begin{array}{l}\text { Master mix }(\mu \mathrm{l}) \\ \text { Primer mix containing }\end{array} & 12.5 & 12.5 \\ \begin{array}{l}\text { 16 STR }\left(\text { Powerplex }{ }^{\mathrm{TM}} 16\right) \\ \left.(2000): 1 \text { in } 2 \times 10^{17}\right)\end{array} & 12.5 & 12.5 \\ \begin{array}{l}1.2 \mathrm{~mm} \text { blood disk } \\ \text { Positive DNA control }(\mu \mathrm{l})\end{array} & \text { Absent } & \begin{array}{l}\text { Present } \\ \text { Nil }\end{array}\end{array}$

The STR-Short tandem repeats were labeled with specific dye (multiplex STRs with fluorescent dyes). The positive control and test samples (alleged fathers and child) sample was then loaded into the Thermal cycler for polymerase chain reaction (PCR).

The following protocol was adopted in this human DNA amplification using selected short tandem repeat primers labeled with fluorescent dyes. The PCR machine was programmed with the following conditions.

1) Initial denaturation at $95^{\circ} \mathrm{C}$ for 11 minutes;

2) Denaturation at $95^{\circ} \mathrm{C}$ for 20 minutes;

3) Annealing at $59^{\circ} \mathrm{C}$ for 2 minutes;

4) Extension at $72^{\circ} \mathrm{C}$ for 1 minute;

5) Go to step 2 for 26 cycles;

6) Final extension at $60^{\circ} \mathrm{C}$ for 25 minutes;

7) Final holding at $4^{\circ} \mathrm{C}$ forever;

8) $1.0 \mu \mathrm{l}$ of the amplified DNA fragment(s) was denatured with $14.5 \mu \mathrm{l}$ Gene scan at $95^{\circ} \mathrm{C}$ for 5 minutes. It was then transferred into the auto region of the Genetic analyzer (AB1 PRISM 310) for processing as described by life Technology (France). The gel block region of the analyser pumps the polyacrylamide gel (POP4) into the capillary during electrophoresis. The auto sampler region allows automated loading of the denatured sample onto the separation medium from the sampled plate in a programmed order. The detection region housing the 
charged coupled device (CCC) camera enhances fluorescence detection.

On subjecting labeled DNA fragment to capillary electrophoresis on polyacrylamide gel support medium (POP4), they migrate at different electrical mobility across the detection window according to their sizes with the smaller fragments moving faster than the large fragment. The specific labeled DNA fragments are excited by the laser as they pass through the detection window to produce fluorescent light of different wavelength depending on the dye [24]. A series of lenses direct and focus the fluorescent light into a spectrograph. The data collection software (Gene Mapper) collects raw data (spectrograph) and converts it into an electropherogram [25].

\section{Result}

The result of short tandem repeat analysis loci for the three subjects is involved in this study (the alleged father $\mathrm{X}$, alleged father $\mathrm{Y}$ and that of the child $\mathrm{Z}$ are compared).

The DNA profiles shown in Table 1 compare the alleged father DNA profile and that of the child. The similarity in their profiles is supported at 15 loci. This result strongly suggests a probability of $99.99 \%$ paternity and thus this alleged father is the biological father.

There is a marked deviation in Table 2, in which there is a mismatched at nine loci: D8S1179, D21S11, CSFIPO, D3S158, D16S539, D2S1338, D198433, D5S818 and FGA. Since the probability is $99.9 \%$, the alleged father in this case is

Table 1. Comparison of the alleged father $\mathrm{X}$ and Child $\mathrm{Z}$ with STR locus.

\begin{tabular}{ccc}
\hline LOCUS & ALLEGED FATHER X & CHILD Z \\
\hline D81179 & 12,15 & 15,15 \\
D21511 & $31,31.2$ & $31.2,32$ \\
D75820 & 8,10 & 10,10 \\
CSFIPO & 11,11 & 10,11 \\
THO & 9,9 & 7,9 \\
D35317 & 12,12 & 12,12 \\
D16S539 & 10,12 & 10,12 \\
D2S1338 & 17,22 & 17,22 \\
D19S433 & 13,14 & 12,13 \\
VWA & 14,18 & 14,17 \\
TPOX & 8,8 & 8,9 \\
D18S51 & 16,18 & 16,17 \\
Amelogenin & X, Y & X, Y \\
D5S818 & 12,13 & 11,13 \\
FGA & 22,25 & 22,24 \\
\hline & & \\
\hline & 8,25 & \\
\hline
\end{tabular}


Table 2. Comparison of the alleged Father Y and Child Z loci.

\begin{tabular}{ccc}
\hline LOCUS & ALLEDGED FATHER Y & CHILD Z \\
\hline D8S1179 & 14,14 & 15,16 \\
DZ1S11 & 27,35 & 28,29 \\
D7S820 & 9,10 & 8,10 \\
CSFIPO & 10,10 & 12,12 \\
D3S1358 & 15,15 & 16,17 \\
THOI & 7,8 & 7,7 \\
D13S317 & 12,13 & 11,12 \\
D16S539 & 11,12 & 9,13 \\
D2S1338 & 19,22 & 21,25 \\
D19S433 & 13,13 & $12,15.2$ \\
VWA & 16,18 & 15,16 \\
TPOX & 7,8 & 8,9 \\
D18S51 & 16,17 & 15,17 \\
Amelogenin & XY & XY \\
D5S818 & 8,11 & 12,14 \\
FGA & 21,24 & 20,27 \\
\hline & & \\
\hline
\end{tabular}

excluded as the biological father of this child.

\section{Discussion}

We have taken advantage of the efficacy of short tandem repeats in specifically comparing and identifying DNA loci as a tool in DNA analysis.

In this study, we used the powerplex ${ }^{\circledR} 16 \mathrm{HS}$ system consisting of D8S1179, D21S11, D7S820, CSFIPO, D3S1358, THOI, D13S317, D16S539, D2S1338, D19S433, VWA, TPOX, D18S51, Amelogenin, D5S818 and FGA. STR genotyping was performed by comparison of sample data to allelic ladders and a simultaneous analysis of the 16 STRs and gender identity. Using consensus evaluation method, we observed that the system was accurate, sensitive and above all reproducible. We have used $12.5 \mu \mathrm{l}$ of primer mixture which is equivalent to (powerplex ${ }^{\mathrm{TM}} 16\left(2000: 1\right.$ in $\left.2 \times 10^{17}\right)$. The specificity of the method can be gleamed when are consider the lack of cross-reactivity with a variety of commonly encountered animal species and some microbial pools. This result is made possible through the concurrent use of fluorescent automated sequencers which plays the dual role of the ability to multiplex several loci together. This is again enhanced by the use of polymerase chain reaction which elevates the sensitivity of the method to enable the analysis of cells. As earlier suggested by [26] [27] [28] [29], technical characteristics of the different fluorochromes groups in multiplexes override the molecular characteristics of each STR in their capacity to detect mixtures. This is further collaborated by the fact as shown by [30], that some- 
times difficulties have arisen in real forensic casework when there are mixed samples which may include extraneous contamination, unknown number of contributors or unbalanced proportion of each one in the sample and a varied degree of degradation of the biological materials contributes extensively in the interpretation of sample profiles. Some earlier works have also confirmed this fact.

Consistent with the potential of STRs to discriminate between inherited regions of our DNA that show variation from person to person, the polymorphic property was taken advantage in this work. The similarity in the seperated patterns in Figure 1 for $\mathrm{X}$ and $\mathrm{Z}$ elicits marked identity between the disputed child $\mathrm{Z}$ and the father $\mathrm{X}$. There is however a sharp contrast between the disputed child $Z$ and the father Y. By examining the STRs, unique evidence emerged to establish relationship in the investigation. As shown in Table 1, the 15 STR showed strong similarity in their profile. This shows the fact that the alleged father is most likely the biological father of the child. A $99.9 \%$ similarity is a strong evidence for inclusion.

We observed a marked deviation in Table 2 in which there is a mismatch at the following nine loci: D8S1179, D21S11, CSFIPO, D3S1358, D16S539, D2S1338, D19S433, D5S818 and FGA. This will give a percentage of 56.25 similarity. However, considering the fact that the probability of paternity is $99.9 \%$, there is a strong and compelling evidence for exclusion of this father as a biological father. We show here that despite the fact that humans share overwhelming



KEY: X-Alleged father; Y-Alleged father; Z-Child.

Figure 1. 1.5\% agarose gel electrophoresis image stained with ethidium bromide. 

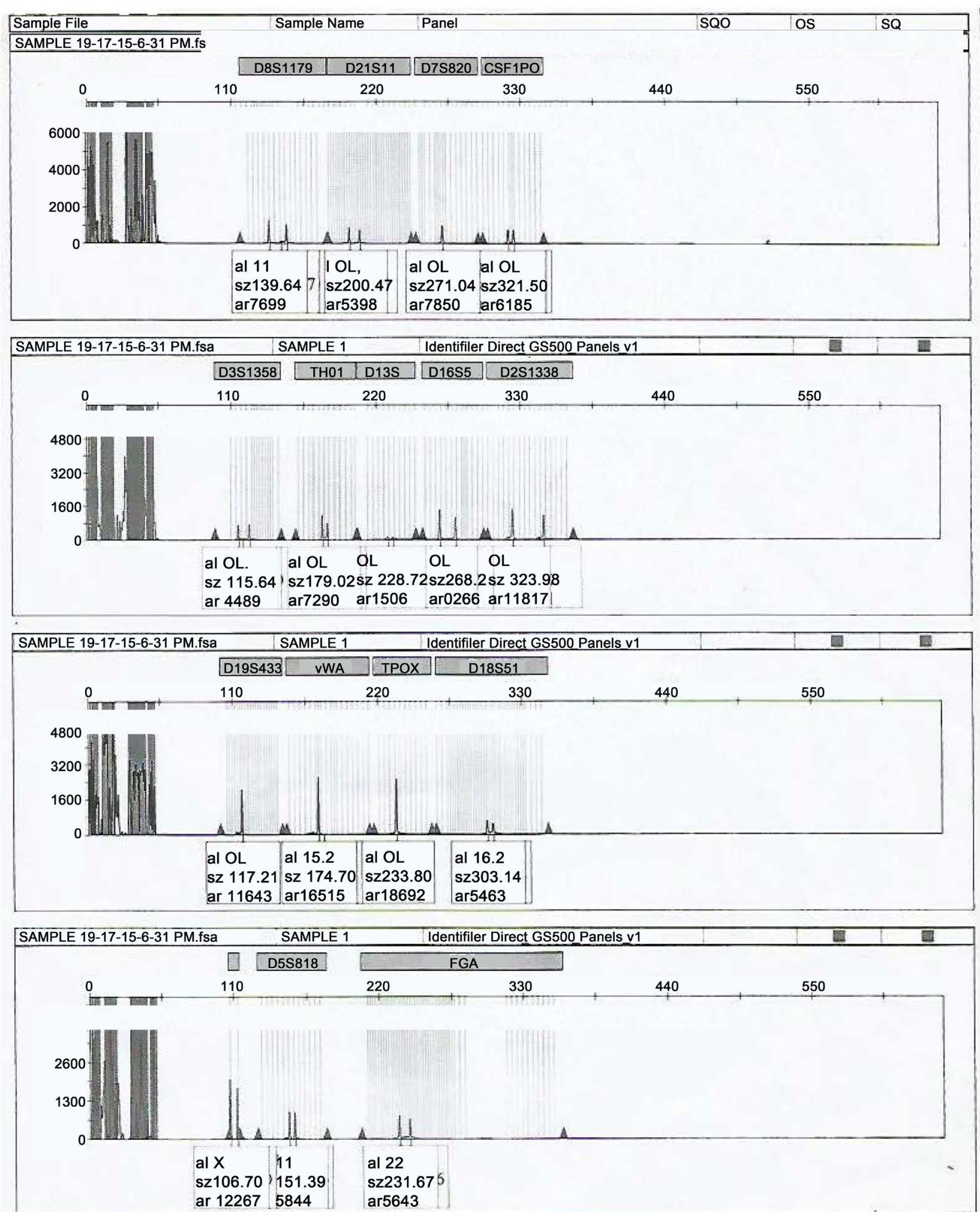

Figure 2. Spectograph of 16 STRs ran on ABI 310 sequencer with Genemapper ID.

majority of the same DNA, the tiny fraction of a\% that varies has been exploited to create a profile of the individual.

In separating the DNA, the procedure used includes PCR amplification and a 
further determination of the amplicon to have the knowledge of the number of repeat units in each alleles. By using capillary or gel electrophoresis the STRs were fluorescently labeled during the PCR. This was possible since either the forward or reverse locus-specific primer contains a fluorescent dye. To determine the size of each STR allele, we recorded the dye colour and migration time of each DNA fragments in relation to an internal standard. The Applied Biosystem PRISM 310 genetic analyzer and genemapper were used to generate the spectrogram show in Figure 2 elucidating the 16 STRs. Genetic analysis is enhanced using STR matrix as potent markers. The benefits derivable from these techniques have enhanced DNA analysis. In spite of the enormity and varied forms of STRs that are contained in the human genome, only a few set of loci have been selected for use in forensic DNA and human identity testing. It is important to note that core loci allow equivalent genetic information to be shared and compared.

\section{Conclusions}

The objective of this research was to identify nucleotide tandem repeats in the DNA sequences of the subjects that we have studied. The number of repeats is variable in populations of DNA and within the alleles of individual serving as markers.

The novelty here is a lack of cross reactivity which is commonly encountered in animal studies and makes the expression of polymorphic properties evident.

\section{Acknowledgements}

We acknowledge and strongly appreciate the support provided by Lahor Laboratories for the use of equipment and reagents to enhance the study.

\section{References}

[1] Butler, J.M. (2005) Forensic DNA Typing: Biology Technology and Genetics of STR Markers. 2nd Edition, Elsevier Academic Press, New York.

[2] Butler, J.M. (2006) Genetics and Genomics of Core STR Used in Human Identity Testing. Journal of Forensic Sciences, 51, 253-265. https://doi.org/10.1111/j.1556-4029.2006.00046.x

[3] Collins, P.J., Henessy, L.P., Leibelt, C.S., Roby, R.K., Reeder, D.J. and Foxal, P.A. (2004) Developmental Validation of a Single-Tube Amplification of the 13 CODSIS STR Loci, D2S1338, D19S433, and Amelogenin: The AmpF/STR ${ }^{\circledR}$ Identifier PCR Amplification Kit. Journal of Forensic Sciences, 49, 1265-1277. https://doi.org/10.1520/JFS2002195

[4] Scientific Working Group on DNA Analysis Methods (SWGDAM) (2000) Short Tandem Repeat STR Interpretation Guidelines. www.fbi.gov/hq/lab/fsc/backissu/july2000/sttrig.html

[5] Whitaker, et al. (1995) The Forensic Science Service in Running a Degraded DNA Samples from Remains of Victims of the Branch Davidian Fire in Waw, Texas Find That Smaller STRs in Their 4-Plex Work Better than Larger Loci. BioTechniques, 18, 670-677. 
[6] Dixon, L.A., Dobbins, A.E., Paulker, H.K., Butler, J.M., Vallone, P.M., Coble, M.D., Parson, W. and Berger, B. (2006) Analysis of Artificially Degraded DNA Using STRs and SNPs-Result of a Collaborative European (EDNAP) Exercise. Forensic Science International, 164, 33-44. https://doi.org/10.1016/j.forsciint.2005.11.011

[7] Gill, P. (2002) Role of Short Tandem Repeat DNA in Forensic Casework in the UK-Past, Present and Future Perspectives. BioTechniques, 32, 366-370.

[8] Gill, P., Werrett, D.J., Budowle, B. and Guerrieri, R. (2004) An Assessment of Wether SNPs Will Replace STRs in National Databases Joint Considerations of the DNA Working Group of the European Network of Forensic Science Institute (ENFSI) and the Scientific Working Groups of DNA Analysis Methods (SWGDAM). Science \& Justice, 44, 51-53. https://doi.org/10.1016/S1355-0306(04)71685-8

[9] Gjertson, D.W., Brenner, C.H., Bau, M.P., Carracedo, A., Guidet, F., Luque, J.A., Lessig, R., Mayr, W.R., Pascali, V.L., Prinz, M., Schneider, P.M. and Morling, N. (2007) ISFG: Recommendation on Biostatistics in Paternity Testing. Forensic Science International: Genetics, 1, 223-231. https://doi.org/10.1016/j.fsigen.2007.06.006

[10] Butler, J.M., Buel, E., Crivellente, F. and McCord, B.R. (2004) Forensic DNA Typing by Capillary Electrophoresis Using ABI Prism 310 Are 3100 Genetic Analyzers for STR Analysis. Electrophoresis, 25, 1397-1412. https://doi.org/10.1002/elps.200305822

[11] Norton, A. and Ozzie, Z. (2008) Which Half Is Mommy?: Tettragametic Chimerism and Trans-Subjectivity. Woman's Studies Quarterly, 36, 106-125.

[12] Liu, P., Seo, T.S., Beyor, N., Shin. R.J., Scherer, J.R. and Mathies, R.A. (2007) Integrated Potable Polymerase Chain Reaction-Capillary Electrophoresis Microsystem for Rapid Forensic Short Tandem Repeat Typing. Analytical Chemistry, 79, 1181-1889. https://doi.org/10.1021/ac061961k

[13] Butler, J.M., Li, J., Shaler, T.A., Moriforte, J.A. and Becker, C.H. (1998) Reliable Genotyping of Short Tandem Repeat Loci without an Ellelic Ladder Using Time-of-Flight Mass Spectrometry. International Journal of Legal Medicine, 112, 45-49. https://doi.org/10.1007/s004140050197

[14] Giusti, W.G. and Adriano, T. (1993) Synthesis and Characterization of 5'-Fluorescent-Dye-Labeled Oligonucleotides. Genome Research, 2, 223-227. https://doi.org/10.1101/gr.2.3.223

[15] Oberacher, H., Pitterl, F., Huber, G., Niederstatter, H., Steinlehner, M. and Parson, W. (2008) Increased Forensic Efficiency of DNA Finger Prints through Simultaneous Resolution of Length and Nucleotide Variability by High-Performance Mass Spectrometry. Human Mutation, 29, 427-432.

[16] Wiegand, P. and Klieber, M. (2000) Less Is More-Length Reduction of STR Amplicons Using Redesigned Primers. International Journal of Legal Medicine, 114, 285-287. https://doi.org/10.1007/s004140000162

[17] Butler, J.M., Sher, Y. and McCord, B.R. (2003) The Development of Reduced Sized STR Amplicons as Tools for Analysis Degraded DNA. Journal of Forensic Sciences, 48, 1054-1064. https://doi.org/10.1520/JFS2003043

[18] John, M.B., Eric, B. and Bruce, R.M. (2004) Forensic DNA Typing by Capillary Electrophoresis Using the ABI Prism 310 and 3100 Genetic Analyzers for STR Analysis. Electrophoresis, 25, 1397-1412. https://doi.org/10.1002/elps.200305822

[19] Budowled, B., Van Daal, A. (2009) Extracting Evidence from Forensic DNA Analysis: Future Molecular Biology Directions. BioTechniques, 46, 339-340. 
https://doi.org/10.2144/000113136

[20] Anderson, H., Fujimori, S., Ota, M., Oki, T. and Fukushima, H. (2008) Evaluation of MiniY-STR Multiplex PCR Systems for Extended 16 Y-STR Loci. International Journal of Legal Medicine, 122, 43-49.

[21] Bonnet, J., Colotte, M., Coudy, D., Couallier, V., Porter, J., Morin, B. and Tuffet, S. (2010) Chain and Conformation Stability of Solid-State DNA: Implication for Room Temperature Storage. Nucleic Acids Research, 38, 1531-1546. https://doi.org/10.1093/nar/gkp1060

[22] Gill, P., Whitaker, J., Flaxman, C., Brown, N. and Buckleton, J. (2000) An Investigation of the Rigor of Interpretation Rules for STRs Derived from Less than 100 pg of DNA. Forensic Science International, 112, 17-40. https://doi.org/10.1016/S0379-0738(00)00158-4

[23] National Institute of Justice (NIJ) (2000) The Future of Forensic DNA Testing: Predictions of the Research and Development Working Group of the National Commission on the Future of DNA Evidence. Washington DC.

[24] Hill, B. (2011) Characterization of the 26 Mini STR Loci under Development of the NIST. Promega Meeting, Nashville.

[25] Hill, C.R., Kline, M.C., Mulero, J.J., Lagale, R.E., Chang, C.W., Henessy, L.K. and Butler, J.M. (2007)) Concordance Study between the AmpF/STR ${ }^{\circledR}$ MumiFiler $^{\mathrm{TM}}$ PCR Amplification Kit and Conventional STR Typing Kits. Journal of Forensic Sciences, 52, 870-873. https://doi.org/10.1111/j.1556-4029.2007.00491.x

[26] Leibelt, C., Budorole, B., Collins, P., Daoudi, Y., Morreti, T., Nunn, G., Reeder, D. and Roby, R. (2003) Identification of a D8S1179 Primer Binding Site Mutation and the Validation of a Primer Designed to Recover Null Alleles. Forensic Science International, 133, 220-227. https://doi.org/10.1016/S0379-0738(03)00035-5

[27] Lederer, T., Braunschweiger, G., Betz, P. and Seidl, S. (2002) Purification of STR-Multiplex Amplified Microsamples Can Enhance Signal Intensity in Capillary Electrophoresis. International Journal of Legal Medicine, 116, 165-169. https://doi.org/10.1007/s00414-001-0277-4

[28] Hofreiter, M., Serre, D., Poiriar, H.N., Kuch, M. and Paabo, S. (2001) Ancient DNA. Nature Reviews Genetics, 2, 353-359. https://doi.org/10.1038/35072071

[29] Hansnon, E.K. and Ballentyne, J. (2005) Whole Genome Amplification Strategy for Forensic Genetic Analysis Using Single or Few Cell Equivalent Genomic DNA. Analytical Biochemistry, 346, 246-257. https://doi.org/10.1016/j.ab.2005.08.017

[30] Phipps, M. and Petricevics, S. (2007) The Tendency of Individuals to Transfer DNA to Handled Items. Forensic Science International, 168, 162-168. https://doi.org/10.1016/j.forsciint.2006.07.010 